J. Clin. Chem. Clin. Biochem.

Vol. 16, 1978, pp. 407-411

\title{
An Improved and Simple Micro-method of Sphingomyelinase Assay in Leukocytes and Urine
}

\author{
By D. Seidel, J. Klenke $\left.{ }^{1}\right)$, G. Fischer and H. Pilz† \\ Neurologische Universitäts-Klinik Hamburg
}

(Received December 19, 1977/April 24, 1978)

Summary: A simple one-vial-method was developed for the quantitative determination of sphingomyelinase activity in human leukocytes and urine, using $\left[{ }^{14} \mathrm{C}\right.$-methyl] sphingomyelin. The measured activities of healthy control persons show a higher scatter in $(\mathrm{n}=50)$ urine $(1.2 \pm 0.5 \mathrm{nmol} / \mathrm{h} \cdot \mathrm{ml}$ urine $)$ than in $(\mathrm{n}=9)$ leukocytes $(2.15 \pm 0.35 \mathrm{nmol} / \mathrm{h} \cdot \mathrm{mg}$ protein). Long term tests showed that the enzyme activities in urine can best be correlated to the 24-h-creatinine excretion. A distinct loss of enzyme activity was found in dialyzed urine starting at about the third day; this did not occur in undialyzed urine. The method also shows good reproducibility in micro-tests. It is therefore suitable for screening tests (urine of persons suffering from Niemann-Pick disease) and for the prenatal diagnosis of sphingomyelinosis.

For one out of two children with symptoms of sphingomyelinosis (hepatosplenomegaly, mental retardation, and neurological deterioration) the diagnosis was confirmed by morphological examination of tissues obtained by biopsy. In both cases leukocytes and urine revealed normal sphingomyelinase activity. These biochemical results in conjunction with the clinical and morphological picture were indicative of type C Niemann-Pick disease.

\section{Eine Mikromethode zur Bestimmung von Sphingomyelinase in Leukocyten und Urin}

Zusammenfassung: Eine leicht durchführbare Methode zur quantitativen Bestimmung der Sphingomyelinaseaktivität in Leukocyten und Urin wird vorgestellt. Als Substrat dient das käufliche $\left[{ }^{14} \mathrm{C}-M e t h y l\right]$ Sphingomyelin. Die im Urin $(\mathrm{n}=50)$ gemessene Enzymaktivität gesunder Versuchspersonen weist mit $1,2 \pm 0,5 \mathrm{nmol} / \mathrm{h} \cdot \mathrm{ml}$ Urin, verglichen mit den Werten für Leukocytenprotein ( $\mathrm{n}=9) \mathrm{mit} 2,15 \pm 0,35 \mathrm{nmol} / \mathrm{h} \cdot \mathrm{mg}$ Protein, eine größere Streuung um den Mittelwert auf.

In einem Langzeitversuch über drei Wochen konnte gezeigt werden, daß sich die täglich im Urin ermittelten Enzymaktivitäten am engsten zur 24-Stunden-Kreatininausscheidung korrelieren lassen. Am dialysierten Urin trat etwa ab dem dritten Tag ein deutlicher Enzymaktivitätsverlust gegenüber undialysiertem Urin auf.

Wegen der Zuverlässigkeit der Methode gerade im Mikrobereich eignet sie sich für klinisch-diagnostische Zwecke (Screening-Untersuchungen und pränatale Diagnostik der Sphingomyelinosen).

Zwèi Kinder wieseñ etwa ab dem dritten Lebeñjjahr żunehmend Sÿmptome (Hepatosplenomegalie, geistiger Entwicklungsrückstand und neurologische Störungen) auf, die an eine Lipidspeicherkrankheit denken ließen. Tatsächlich wurde in dem einen untersuchten Fall die Diagnose einer Sphingomyelinose lichtmikroskopisch und elektronenoptisch an Biopsiematerial gesichert. Die normale Sphingomyelinaseaktivität in Leukocyten und Urin erlaubte eine Zuordnung zum prognostisch relativ günstigeren Typ C der Niemann-Pick-Erkrankung.

\section{Introduction}

For the diagnosis of lyṣosomal disorders, acid hydrolases are mëasured, preferably in leukocytes, serum, cultured skin-fibroblasts and sometimes also in urine. The sources of these enzymes in prenatal diagnosis are native or cultured amnion cells and amniotic fluid.

In most cases synthetic chromogenic (1) and fluorogenic substrates are employed for the enzyme determ-

\footnotetext{
1) These studies are part of the thesis of $J$. Klenke (5).
}

ination. There are, however, aspects of the diseases, which so far can only be ascertained by use of radioactively labelled, natural substrates. Several of these labelled substances, especially sphingolipids, can now be purchased, and this leads to a simplification of the tests.

Either the hydrophobic part of the sphingolipid molecule (e.g. by tritiation of the double-bond of sphingosine) (2), or the hydrophilic part $(3,4,6,7)$ can be labelled. The latter type of labelling is found in one of the commercially available sphingomyelins, where the ${ }^{14} \mathrm{C}$-marker is 
localized on the methyl-groups of the phosphorylcholine. After the reaction has been accomplished, substrate (sphingomyelin) and the reaction product phosphorylcholine can be separated by a simple Folch-phase-distribution (6-8). Since often only minimum amounts of enzyme are available, and because of radioactive hazards, a micro-method seems most suitable.

In our laboratory a one-vial-method for sphingomyelinase determination with a good reproducibility was developed. By means of this method sphingomyelinase activity in leukocytes and urine of healthy control persons has been determined.

In addition, the urine of two normal persons was kept at room temperature, and the amount of sphingomyelinase was measured daily for three weeks, and correlated to a possible reference parameter.

\section{Material and Methods}

\section{Control persons}

For the assay of the sphingomyelinase activity in leukocytes, blood samples were taken from healthy test persons (laboratory personnel) of different age and sex. The urine of two students (male 28 years, female 30 years) was collected daily over a period of three weeks, and used for determination of the enzyme excretion. The assay of the creatinine-clearance proved that both test persons had no renal defect.

\section{Leukocyte preparation}

Chemicals: 25000 USP-E heparin (e.g. $5 \mathrm{ml}$ Liquemin) are added to a solution of $25 \mathrm{~g}$ dextran (Sigma, $\mathrm{M}_{\mathrm{r}} 200000-275000$ ) and $3.5 \mathrm{~g} \mathrm{NaCl}$ in $500 \mathrm{ml}$ distilled water.

According to the method of Kampine (4), $5 \mathrm{ml}$ venous blood were collected in a syringe prepared with heparin. The blood was added to a test tube, containing $1 \mathrm{ml}$ of the above dextran solution, carefully mixed, and kept at room temperature for approx. 45-60 minutes. The overlay (plasma and leukocytes) was removed and transferred to a pre-weighed centrifuge tube. After centrifugation (10 min at $2700 \mathrm{rpm}$ ) the overlay was removed. The pellet contains leukocytes and some erythrocytes Red blood cells were removed by mixing the pellet with $5 \mathrm{ml}$ ice-cold distilled water, followed by the addition of $5 \mathrm{ml} 17 \mathrm{~g} / \mathrm{l}$ $\mathrm{NaCl}$ solution. After repeated centrifugation the remaining aqueous phase was discarded. The wet leukocy tes were weighed, and the leukocyte pellet combined with 6 vol. of distilled water. The mixture was then homogenized, followed by addition of 2 vol. of solvent (containing distilled water and $2 \mathrm{mmol} / 1$ of the detergent taurodeoxycholate, TDC Sigma, in a ratio of 3 vol. + 1 vol). The protein content was determined by the method of Lowry (9).

\section{Examination of native urine}

$10 \mathrm{ml}$ of a $24 \mathrm{~h}$ urine sample were filtered (filter paper). The

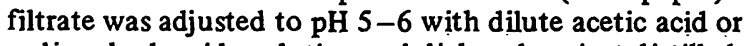
sodium hydroxide solution and dialyzed against distilled water for $24 \mathrm{~h}$ at $4^{\circ} \mathrm{C}$. The volume must be measured again after dialysis. The creatinine contents of serum and urine were determined with the Jaffe method (formation of a coloured complex with picric acid), using a test kit (Boehringer Mannheim, Nr. 124 192).

\section{Sphingom yelinase assay}

$370 \mathrm{kBq}(10 \mu \mathrm{Ci})$ of the commercially available sphingomyelin (Amersham-Buchler) (specific activity $2220 \mathrm{GBq} / \mathrm{mol}$ $(60 \mathrm{mCi} / \mathrm{mmol})),{ }^{14} \mathrm{C}$-labelled in the methyl groups of the choline part of the molecule, was diluted with $34 \mathrm{mg}$ pure, cold sphingomyelin $\left(M_{\mathbf{r}} 780\right)$ (Koch-Light), and dissolved in $50 \mathrm{ml}$ benzene/ethanol $25 \mathrm{ml}+25 \mathrm{ml}$. The specific activity was then $8736 \mathrm{MBq} / \mathrm{mol}(228 \mu \mathrm{Ci} / \mathrm{mmol})$. For the sphingomyelinase assay $25 \mu$ l of the marked $\left[{ }^{14} \mathrm{C}\right]$ sphingomyelin $(23 \mathrm{nmol})$ were transferred to an Eppendorf reaction vial, and the solvent was evaporated. The residue was resuspended in $100 \mu / 2 \mathrm{~g} / 1$ Triton X-100 in $0.1 \mathrm{~mol} / 1$ sodium acetate buffer pH 5.0, using ultrasonic treatment; then $50 \mu$ l solvent (containing distilled water and $2 \mathrm{mmol} / 1$ TDC in a ratio of $3 \mathrm{vol} .+1 \mathrm{vol}$.) and $50 \mu 1$ enzyme solution were added. The total volume of the reaction mixture was $200 \mu 1$.

After incubation for 24 hours at $37^{\circ} \mathrm{C}$, the reaction was stopped by adding $800 \mu \mathrm{l}$ chloroform/methanol $200 \mathrm{ml}+100 \mathrm{ml}$. Two phases in a ratio 1 vol. +2 vol. were separated by centrifugation. The aqueous upper phase contained the split phosphoryl $\left[{ }^{14} \mathrm{C}\right]$ choline; the lower phase includes the unchanged $\left[{ }^{14} \mathrm{C}\right]$ sphingomyelin. Aliquots $(150 \mu l$ of the upper phase and $300 \mu l$ of the lower phase) are transferred to scintillation vials. The solvents were evaporated under infrared light with a stream of nitrogen. After addition of $15 \mathrm{ml}$ of scintillator solution (Unisolve 1 , Koch-Light), the radioactivity was measured in a scintillation counter (Packard, model Tricarb No. 2425).

\section{Analysis}

upper phase counts/min

upper phase counts/min + lower phase counts/min degraded fraction

Evaluation:

degraded fraction $\times 23 \times 1000$

$24 \times \mu \mathrm{g}$ protein in $50 \mu \mathrm{l}$ leukocyte extract

degraded fraction $\times 23 \times 20$

24

Reference enzyme

$\alpha$-glucosidase, as a reference enzyme with the fluorogenic substrate 4-methylumbelliferol- $\alpha$-glucopyranoside (Sigma), was tested at the same time.

\section{Results}

For prior examination, increasing amounts of leukocyte protein were added to test the relation between the amount of hydrolyzed sphingomyelin and the amount of enzyme added. Even with small amounts of protein, the relation was nearly linear (fig. 1).

Batches of $100 \mu \mathrm{g}$ leukocyte protein were incubated for different periods of time under the conditions indicated above. Even for short incubation periods the relation was linear (fig. 2).

In addition batches of $25 \mu$ leukocyte extract (equivalent to ca. $40 \mu \mathrm{g}$ protein) were incubated with increasing amounts of substrate $(9-110 \mathrm{nmol}$ sphingomyelin). The amount of free phosphorylcholine was constant. Substrate is actually required in excess for the measurement of enzyme activity. A degradation less than 0.005 was obtained with routinely performed controls containing no, or heat-denaturated enzyme protein.

Sphingomyelinase activity (mean value) in leukocytes of 9 normal persons was $2.15 \mathrm{nmol} / \mathrm{h} \cdot \mathrm{mg}$ protein (standard deviation $s=0.35$, coefficient of variation $\mathrm{CV}=16 \%$ ), and (mean value $\overline{\mathrm{x}}$ ) $1.2 \mathrm{nmol} / \mathrm{h} \cdot \mathrm{ml}$ in 


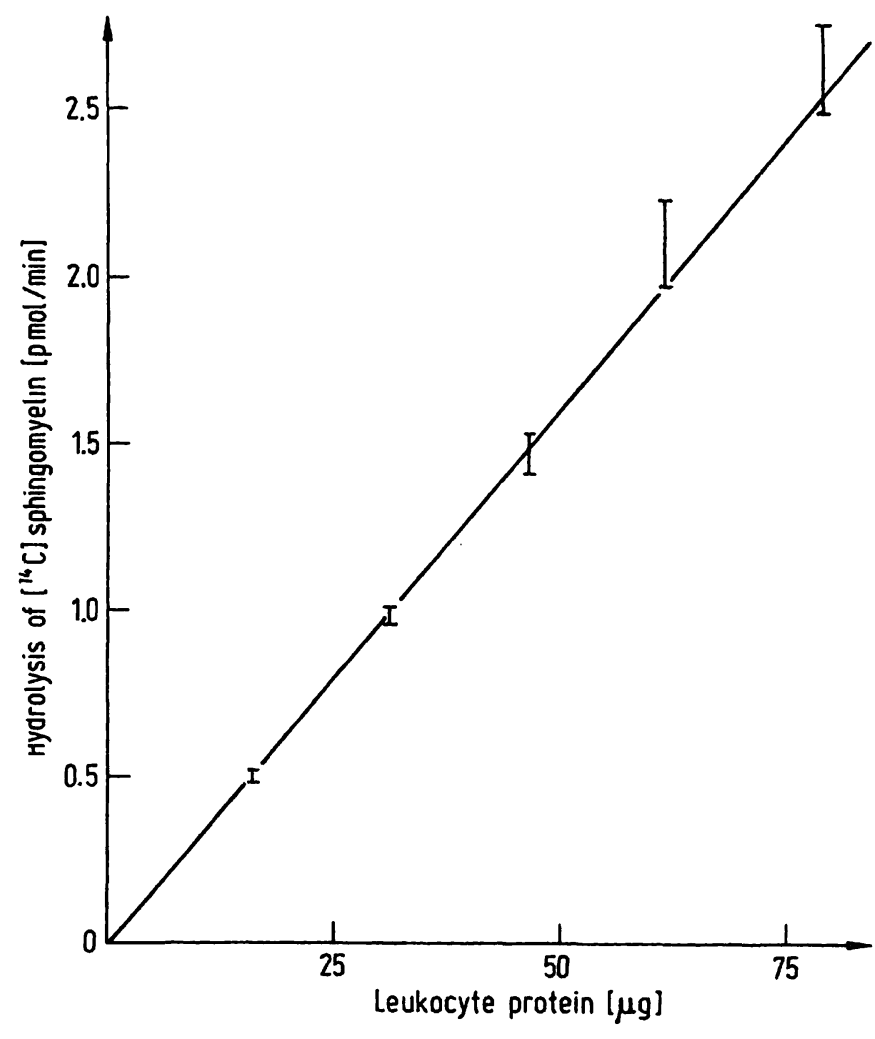

Fig. 1. Cleavage of ${ }^{14} \mathrm{C}$-sphingomyelin with various amounts of leukocyte protein. Ordinate: amount of ${ }^{14} \mathrm{C}$-sphingomyelin hydrolyzed expressed as pmol/h. Abscissa: amount of added protein [ $\mu \mathrm{g}$ ].

Further details see: Material and Methods.

urine $(n=50, s=0.5, C V=41.6 \%)$. The enzyme activities measured in urine were notably more scattered. Therefore, the sphingomyelinase activity in the urine of two healthy test persons was measured over a period of three weeks and related to the daily urine excretion, the daily excretion of creatinine, and $\alpha$-glucosidase as reference enżyme for the 24-hour-urine. The mean value, standard deviation, and coefficient of variation were calculated from the daily determined relation coefficients (tab. 1).

Furthermore, urine samples were tested daily for a period of six days, to see whether storage of urine at room temperature causes a decrease of activity. It turned out that no significant decline of sphingomyelin-

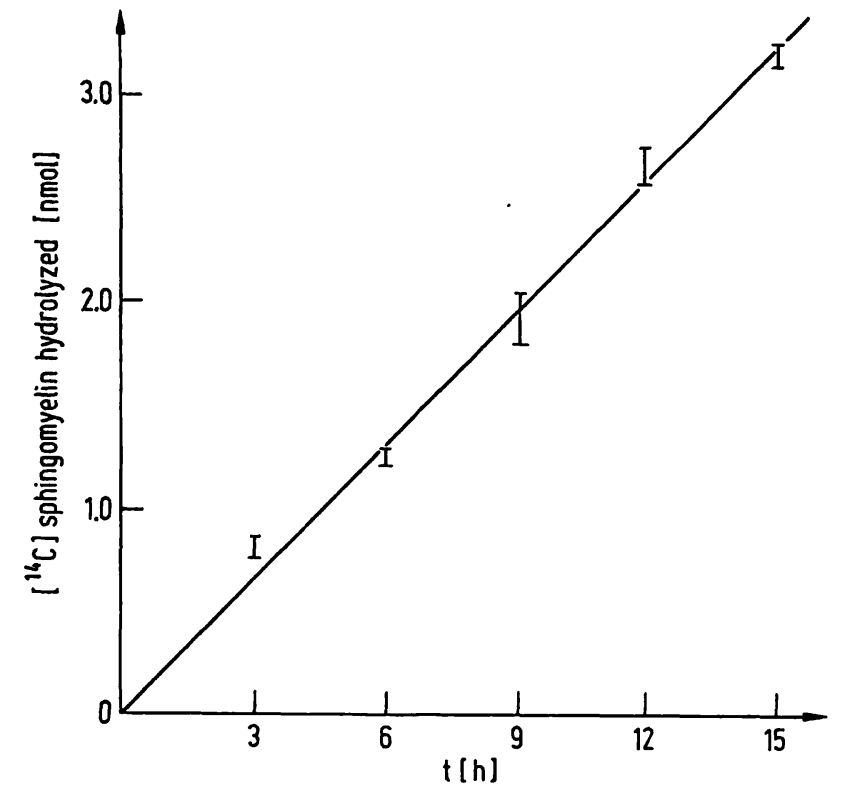

Fig. 2. Time-dependence of the cleavage of ${ }^{14} \mathrm{C}$-sphingomyelin. Amount of ${ }^{14} \mathrm{C}$-sphingomyelin hydrolyzed expressed as nmol after addition of $100 \mu \mathrm{g}$ leukocyte protein as a function of time.

Further details see: Material and Methods.

ase and $\alpha$-glucosidase activity could be observed for the undialyzed urine. Yet, from the third day on, dialyzed urine samples showed a decrease to $30-0 \%$ of the initial enzyme activity.

\section{Discussion}

The common method for the determination of sphingomyelinase activity is based on the precipitation of marked undegraded sphingomyelin with concentrated trichloroacetic acid. Our method is based on the direct phase separation of degraded water-soluble phosphorylcholine and water-insoluble sphingomyelin (6-8). This method is not only more sensitive, but it also has a good reproducibility of the degradation rates for the labelled substrate. Deviation of the degradation rates was not higher than $10 \%$ in simultaneous tests.

Our sphingomyelinase activity in leukocytes is lower than the values reported by Kampine (4) evaluated with

Tab. 1. Sphingomyelinase activity, $\alpha$-glucosidase activity and creatinine excretion in urine (estimated daily for three weeks).

\begin{tabular}{|c|c|c|c|c|}
\hline & \multicolumn{2}{|c|}{ J.K. $\delta 28$ a } & \multicolumn{2}{|c|}{ S.K. $\& 30$ a } \\
\hline $\begin{array}{l}\text { sphingomyelinase excretion in 24-h-urine } \\
\text { (sphingomyelin hydrolyzed [ } \mu \mathrm{mol} / 24 \mathrm{~h} \cdot 24-\mathrm{h} \text {-urine ]) }\end{array}$ & $\begin{array}{l}\bar{x} \\
s \\
C V\end{array}$ & $\begin{array}{c}31 \\
8 \\
25.8 \%\end{array}$ & $\begin{array}{l}\bar{x} \\
s \\
C V\end{array}$ & $\begin{array}{c}22.5 \\
5.9 \\
26.2 \%\end{array}$ \\
\hline sphịgomyelinase excretion in 24 -h-urine [ $\mu \mathrm{mol} / 24 \mathrm{~h} \cdot 24-\mathrm{h}$-ưrine] & & 19 & $\bar{x}$ & 1738 \\
\hline creatinine excretion in 24-h=urine [g/24:h=urine] & CV & $21.6 \%$ & $\mathrm{CV}$ & $22.3 \%$ \\
\hline$\alpha$-glucosidase excretion in 24-h-urine [ $\mu$ mol/h $\cdot 24$-h-urine] & $\overline{\mathbf{x}}$ & 5.8 & $\overline{\mathbf{x}}$ & 7.4 \\
\hline sphingomyelinase excretion in 24-h-urine [ $\mu \mathrm{mol} / 24 \mathrm{~h} \cdot 24-\mathrm{h}$-urine] & $\stackrel{s}{\mathrm{CV}}$ & $27.6 \%$ & $\stackrel{s}{\mathrm{CV}}$ & $\begin{array}{ll}1.7 \\
23.0 \%\end{array}$ \\
\hline
\end{tabular}


a different method (3.2-5.6 nmol/h $\cdot \mathrm{mg}$ protein). Our values, however, show a much lower scattering. They are in the range of leukocyte protein values reported by Gal et al. (2.2-3.7 nmol/h $\cdot \mathrm{mg}$ protein) (1). However, the latter authors regard $\left[{ }^{14} \mathrm{C}\right]$ sphingomyelin as the preferred substrate for sphingomyelinase assays in leukocyte preparations, owing to the poor degradation rate of their chromogenic substrate (2-hexadecanoylamino-4nitrophenylphosphorylcholine) by leukocyte protein.

Problems of enzyme measurements in urine are well known (11). To our knowledge, there are no representative investigations on sphingomyelinase activities in urine. The range of the values is higher for urine than for leukocytes. It has been shown that the measurable enzyme activities in the urine can be most directly correlated to the 24 -hour creatinine excretion (11).

For screening of sphingomyelinase deficiency in urine the stability of the enzyme is of great importance, because the material is often sent through the post. In fact, there will be no important loss of enzyme activity.

$\alpha$-glucosidase, as a reference enzyme, was measured every day in the urine of the two persons over a period of three weeks. This enzyme has a higher degree of scattering than sphingomyelinase. In spite of this fact 1-2 reference enzymes should be tested simultaneously to eliminate interfering artefacts (bacterial influence, medication). Our finding, that within 6 days no significant decrease of the enzyme activity in the undialyzed urine was observed, is of great practical importance. However, the dialyzed urine always showed nearly a complete decrease of the measurable activity, beginning at about the third day of dialysis. This may result from the loss of ions caused by dialysis.

Test results of numerous authors indicate that the actual enzyme deficiencies in vivo are more reliably reflected, if natural instead of synthetic substrates are used. In addition the employment of radioactively labelled natural substrate allows a microscale assay that requires only small amounts of enzyme. This may be important for pediatric examinations, family tests, or for prenatal diagnosis.

In a family (family F. from East-Frisia) two out of three children both starting with the third year of age showed mental retardation and neurological deterioration combined with hepatosplenomegaly. The light microscopic and electronic optical examination of bone marrow and rectal mucous membrane obtained by biopsy revealed a typical picture of sphingomyelin storage disease for the examined second child. Both children are still alive. They are now five and seven years old. However, no decrease in sphingomyelinase activity was found in leukocytes and urine for any member of the family (tab. 2). Based on the classification of sphingomyelinoses according to biochemical and clinical criteria proposed by Frederickson et al. (10), the mentioned cases can be related to type $C$ Niemann-Pick disease. That type is the one with the mildest course of storage disease and therefore it has a relatively favourable prognọsis.

\section{Acknowledgment}

The investigations were financially supported by Deutsche Forschungsgemeinschaft (SFB 33).

Tab. 2. Sphingomyelinase activity in human leukocytes and urine (Control persons and one family with Niemann-Pick disease).

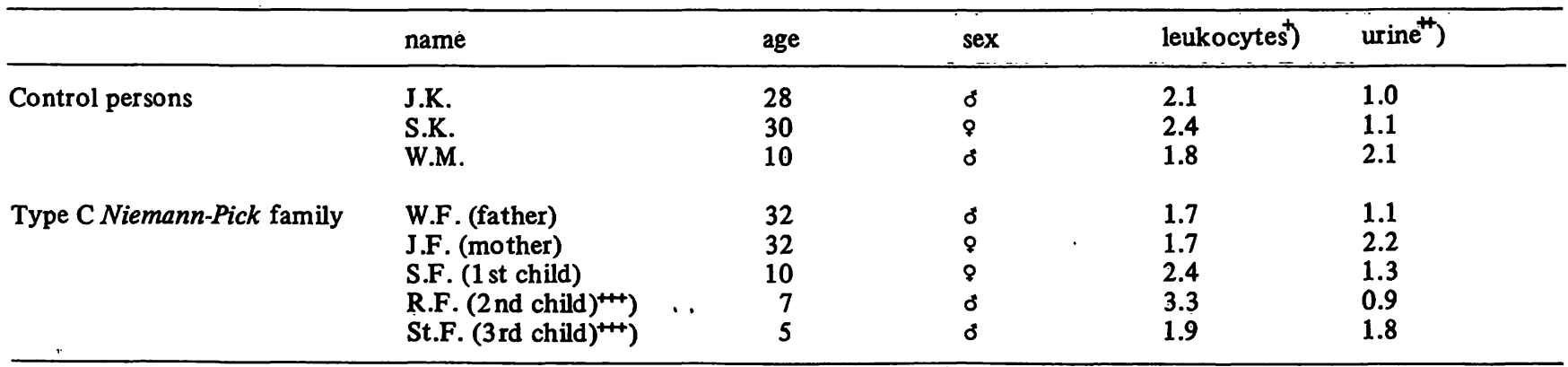

$\left.{ }_{+}^{+}\right)$sphingomyelin hydrolyzed [nmol/h $\cdot \mathrm{mg}$ protein]

H) sphingomyelin hydrolyzed [ $\mathrm{nmol} / \mathrm{h} \cdot \mathrm{ml}$ dialyzed urine]

H) Compared to the first child these two children were affected by hepatosplenomegaly, mental retardation, and neurological deterioration starting with the third year of age. 


\section{References}

1. Gal, A. E., Brady, R. O., Hibbert, S. R. \& Pentschev, P. G. (1975), New Engl. J. Med., 293, 632-636.

2. Poulos, A. \& Pollard, A. C. (1976), Clin. Chim. Acta 72, 327-335.

3. Brady, R. O., Kanfer, J. N., Mock, M. B. \& Frederickson, D. S. (1966), Biochemistry 55, 366-369.

4. Kampine, J. P., Brady, R. O. \& Kanfer, J. N. (1967), Science $155,86-88$.

5. Klenke, J. Eine vereinfachte Sphingomyelinasebestimmung in Leukozyten und Urin bei Normalpersonen und Patienten mit Niemann-Pick Erkrankung. Dissertationsthema; Med. Fak. der Georg August-Univ. Göttingen.

6. Mraz, W., Fischer, G. \& Jatzkewitz, H. (1976), FEBS-Letters 67, 104-109.
7. Wenger, D. A., Sattler, M., Clark, C., Tanaka, H., Suzuki, K. \& Dawson, G. (1975), Science 188, 1310-1312.

8. Folch-Pi, J., Lees, M. \& Sloane-Stanley, G. H. (1957), J. Biol. Chem. 226, 497-508.

9. Lowry, O. H., Rosebrough, N. J., Farr, A. L. \& Randall, R. J. (1951), J. Biol. Chem. 193, 265-280.

10. Frederickson, D. S. \& Sloane, H. R. (1972), Sphingomyelin lipidoses: Niemann-Pick disease, in The Metabolic Basis of Inherited Diseases, third ed., (Stanbury, J. B., Wyngaarden, J. B. \& Frederickson, D. S., eds.) New York, Mc Graw-Hill, p. 783-807

11. Raab, W. P., (1972), Clin. Chem. 18, 5-25
Dr. D. Seidel Neurolog. Univ.-Klinik

Martinistr. 52

D-2000 Hamburg 20

Federal Republic of Germany 
